\title{
ANALYSIS OF OKUN'S REGULARITY: THE CASE OF BOSNIA AND HERZEGOVINA
}

\author{
Ognjen Erić1, Goran Popović1 ${ }^{1}$ Jelena Bjelić ${ }^{2}$
}

date of paper receipt:

31.10.2020.

Review Article date of sending to review:

02.11.2020.

doi: 10.2478/eoik-2020-0011 date of review receipt:

18.11.2020.

UDK 330.552:338.486.2(497.6)

1University of Banja Luka, Faculty of Economics, Bosnia and Herzegovina

${ }^{2}$ Indirect Taxation Authority, Bosnia and Herzegovina

\begin{abstract}
Economic growth, or, more precisely, GDP growth rate $(\mathrm{Y})$ is the key macroeconomic indicator. Positive tendencies of GDP growth (r) mostly impact the economic welfare of the national economy. Hence, output is analysed in combination with other macroeconomic aggregates and indicators: investments, inflation, unemployment, trade exchange and the like. In the context of researching the relation between GDP trends and unemployment rate, A.M. Okun was the first to notice regularity between these variables. Okun's law shows the direction and strength of GDP changes under the influence of (un)employment and represents functional relation between the output market and labour market. This paper aims to prove that, to a certain extent, there exists Okun's regularity in Bosnian and Herzegovinian economy for the period of 2000-2019. The results of linear regression analysis show that there is negative correlation $(\mathrm{R}=0,451)$ between variables $\mathrm{Y}$ (output) and $\mathrm{X}$ (unemployment). Determination coefficient R2 $=0,204$ indicates that $20,4 \%$ variations in GDP is determined by the changes in unemployment. Coefficient $\beta$ in linear regression equation is negative, amounting to $-0,596$, which means that a change in unemployment by 1 percentile point brings about an inverse change in GDP by approximately 0,6 units. Variable direction indicates that there exists Okun's regularity, though with significantly weaker intensity among the variables. This proves the hypothesis that there is a negative functional relation between the output market and labour market in Bosnia and Herzegovina.
\end{abstract}

\section{Keywords:}

unemployment, GDP, Okun's law, Bosnia and Herzegovina. 


\section{INTRODUCTION}

This law got its name after the American economist, Arthur M. Okun (1928-1980). During the 1960s he was an influential creator of the new, American post-war economic policy. He attended the Columbia University and lectured at Yale. He is known for his ability to provide simple explanations of complex economic problems and complex researches (during the 1960s, Okun was a member of the Economic Advisory Board in Kennedy's Administration, and during the presidency of Lyndon Johnson, he was also the the Board Chair. Inter alia, he researched short-term changes in GDP and unemployment rates in the USA for the period of four years (until the end of World War II). In the course of the research, he arrived at the results which indicated that unemployment generates extremely high and fragmented costs in the whole society (Okun, 1962). They result from slowing down GDP growth, a gap between the achieved and potential aggregate product (output gap) and all the other public expenditures caused by an increase in unemployment rate. In principle, Okun's law basically defines the relation (regularity) between the output and unemployment trends, that is, key macroeconomic units: the height of GDP and the unemployment rate. Okun's law de facto shows to what extent output should be changed in a certain national economy, as a result of changes in (un)employment. It is thereby necessary to emphasise that this analysis is not impacted by changes in prices or worker fees (they have been abstracted). In contrast to harsh criticism addressed to the creator of the Phillips curve, especially that raised by Baily and Friedman (1991), the situation with Okun's law is more favourable, because he has been criticised less, or virtually insignificantly. In doing research on the example of the USA, Okun established that $1 \%$ fall in the unemployment rate raises GDP, that is, the level of production by $3 \%$ above its trend. In actual researches, a rule of thumb is that $1 \%$ drop in unemployment raises production by $2-2,5 \%$ above the trend. However, a generally accepted criterion according to Okun's law is that every $2 \%$ fall in GDP, in relation to the potential one, increases the unemployment rate by $1 \%$. In other words, if GDP falls from the potential $100 \%$ to $96 \%$, the unemployment rate will increase by $2 \%$, which can be considered as the relation which is generally accepted in the modern economic theory and practice. In general, it is considered that $1 \%$ increase in unemployment consequently reduces GDP by $2 \%$, just like it could be said that $2 \%$ GDP fall (in relation to potential GDP) generates $1 \%$ fall in employment (or unemployment increases by $1 \%$ ).

At any rate, researches in which unemployment is represented as one of the variables, are always actual, especially during and after economic crises, because then unemployment occurs as a regular consequence. It is the same today (2020), in the times when the crisis caused by corona virus is escalating. Unemployment rate has accompanied all the bigger crises, such as the global financial crisis 2008/2009, oil crisis during the 1970s, or the Great Depression. During the Great Depression (1929-1939), unemployment rate growth represented the fundamental economic and wider social problem. For, with an extremely high fall in profit and worker fees, there occurred enormous growth in unemployment. It is widely known that in such circumstances there came about an intervention (interfering) on the part of the state in economic policy, that is, the state undertook full responsibility for overcoming the crisis.

Thus, Okun's law, as a general economic regularity, can be used to determine mutual dependence between changes in growth rates (GDP growth) and unemployment rates. Several analyses have confirmed the existence of this regularity in numerous countries. The differences between the countries lie in Okun's coefficients, that is, in GDP changes and unemployment rate coefficients. On the other hand, researches for many countries show that this regularity mainly has a confirmed direction between the observed variables. At any rate, Okun proved that there is negative relation (trade-off) between GDP growth and unemployment rate.

Therefore, Okun's law can be used in various projections of growth and employment.

Okun's regularity shows a functional relation between the output market and labour market. Thus, for example, according to Okun, during crises or shocks there grows unemployment, because both output and aggregate demand fall, and, consequently, aggregate supply decreases too. Okun uses this to show that losses in production related to unemployment are even bigger than the unemployment 
rate shows. On the other hand, Okun connects fluctuations in real GDP with its long-term growth rate, and the fluctuations in the unemployment rate to its balancing point. He has found that when GDP growth is slower, then unemployment grows, and conversely, GDP growth which is faster than its trend decreases unemployment. As has been said, Okun's coefficient has a negative prefix, because he established a negative relation (trade-off) between the fluctuation (growth rate) in GDP and the unemployment rate.

Still, in his research, Okun mostly deals with the problems of inflation, primarily in the context of controlling it. Okun strongly advocates new anti-inflation measures. In "The Policy of Income Based on Taxes" (1968), he illustrates arguments against tax increase (Samuelson, \& Nordhaus, 2007). Of course, his research aim is to control inflation, whereby employment shall not be reduced. Therefore, the goal is to ensure simultaneous fall in inflation rates and unemployment. And this is a goal opposite to the essence of the Phillips curve, that is, regularity. But numerous researches still show that Phillips regularity holds, even in developed integration such as the European Union (EU) (Popović, 2010).

Prior to the emergence of the crisis, Bosnia and Herzegovina records high growth rates (about $6 \%$ until 2008). Since 2015, growth rates amount to around $3 \%$, while the average unemployment rate for the observed period is around 26\%, whereby it should be noted that in 2018 and 2019 unemployment was significantly below the average. The research starts with the hypothesis that unemployment and GDP trends in Bosnia and Herzegovina stand in an inverse relation, and that they are ranging within limits that are somewhat lower, yet approximate to Okun's regularity.

Table 1. Unemployment, GDP, GDP growth in Bosnia and Herzegovina

\begin{tabular}{|c|c|c|c|}
\hline Series Name & GDP growth (annual \%) & $\begin{array}{c}\text { GDP } \\
\text { (billions USD) }\end{array}$ & $\begin{array}{l}\text { Unemployment } \\
\text { (annual \%) }\end{array}$ \\
\hline 2000 & 5,50 & 5,51 & 25,66 \\
\hline 2001 & 4,40 & 5,75 & 26,60 \\
\hline 2002 & 5,30 & 6,51 & 27,70 \\
\hline 2003 & 4,00 & 8,37 & 28,71 \\
\hline 2004 & 6,10 & 10,6 & 29,59 \\
\hline 2005 & 8,76 & 11,22 & 30,45 \\
\hline 2006 & 5,42 & 12,86 & 31,11 \\
\hline 2007 & 5,86 & 15,78 & 28,98 \\
\hline 2008 & 5,43 & 19,11 & 23,41 \\
\hline 2009 & $-3,00$ & 17,61 & 24,07 \\
\hline 2010 & 0,77 & 17,18 & 27,31 \\
\hline 2011 & 0,91 & 18,64 & 27,58 \\
\hline 2012 & $-0,70$ & 17,23 & 28,01 \\
\hline 2013 & 2,35 & 18,18 & 27,45 \\
\hline 2014 & 1,15 & 18,56 & 27,52 \\
\hline 2015 & 3,09 & 16,21 & 27,69 \\
\hline 2016 & 3,14 & 16,91 & 25,06 \\
\hline 2017 & 3,03 & 18,17 & 25,57 \\
\hline 2018 & 3,72 & 20,18 & 18,40 \\
\hline 2019 & 2,58 & 20,05 & 15,69 \\
\hline
\end{tabular}

Source: World Bank, World Development Indicators, 2020. 
An overview of more recent empirical researches. Pizzo (2020) considers forty-four studies which are focused on evaluating Okun's law in the countries of Latin America and the Caribbean. It is mostly about more recent researches in which he is trying to sum up factors that lead to weaker reaction of unemployment to production growth. In those analyses he reaches the conclusion that developing countries generate lower unemployment coefficients in inversely proportional explanation of the production trends, in relation to the same indicators in the USA.

Dixon et al. (2017) use empirical analysis to test Okun's law and include the effect of institutions on the labour market, age and gender. The sample comprises 20 countries of OECD, and the period is 1985-2013. These authors reveal that the share of part-time workers (which includes a large participation of younger population) has a crucial role in explaining changes in Okun's coefficient during the analysed period. Okun's coefficient is reduced with an increase in older population in the sample. According to these authors, acceleration of the economic growth not only implies reduction in the total rate of unemployment but will also have a distributional effect on the reduction of unemployment in younger population.

Moazzami and Dadgostar (2009) use dynamic ECM model which tests Okun's law in the long run, while monitoring short-term divergences from long-term balance at the same time. Using quartal data for 13 OECD countries covering the period from 1988 to 2007, they find a significant confirmation of Okun's law.

Cahill, M (2006) tests Okun's and Taylor's law through the application of regression models in Excel statistical tools. The source of data is the American FED, and use is made of three time series for the analysis with quartal data (the initial years are 1949, 1973 and 1997). Using empirical analysis, he confirms Okun's law on the sample of all three observed time series.

Dajcman (2018) analyses Okun's regularity using regional approach in Slovenia. He applies the panel model, on the basis of which he finds that Okun's law holds for Slovenia in 6 out of the total 12 regions. The results imply that all the three key questions stated in literature on time series should be solved when evaluating Okun's coefficient with data.

\section{METHODOLOGY AND EXPLANATION OF VARIABLES}

Theoretical fundamentals of Okun's regularity. In a wider sense, Okun's law expresses a relation (interdependence) between key macroeconomic aggregates and indicators: Gross Domestic Product (output) and unemployment rate. Output, that is, GDP is the sum of net-final sales, hence to a certain extent it also determines the height of aggregate demand (indirectly creating aggregate supply too). The height of GDP depends on several factors (variables): capital (K), labour (L) and technological progress (Tp), as well as other (residual) factors (z), which jointly make the production function formula:

$$
Y=f(K, L, T p, \ldots, z)
$$

Engaged labour (employment) and output are moving in the same direction, whereby output has to grow faster than the sum of productivity and population growth (if the goal is decrease in unemployment). The conclusion is that Okun's law connects long-term growth rates with changes in the unemployment rate around its balancing trend. This equality is expressed by means of the following expression:

$$
\mathrm{U}-\hat{\mathrm{U}}=-\mathrm{g}(\mathrm{Y}-\hat{\mathrm{Y}}) \quad \mathrm{g}>0
$$

It is evident that the value of the parameter $\mathrm{g}>0$ is relatively stable. Still, it is negative (-), as unemployment and GDP (output) are inversely related. The left-hand side of the equation represents unemployment (the difference in unemployment in the current and base year), which is brought into connection with the right-hand side, that is, the difference in the real GDP in the current and 
base year. Hence, Okun's law connects the fluctuations of the real GDP (Y) around its long-term growth rate $(\hat{Y})$, with fluctuations in the unemployment rate $(\mathrm{U})$, around the balancing point $(\hat{\mathrm{U}})$. Okun's equation may be used when planning the economic growth and (un)employment.

Graph 1 shows that higher unemployment is accompanied by lower output (the inverse is true, too).

Figure 1. Okun's regularity - GDP and unemployment



Source: Burda \& Wyplosz, 2013, p. 293

Gross Domestic Product (GDP, output, Y) is the key macroeconomic aggregate whose analysis and comparisons with other indicators show the economic state of the national economy. Output (GDP) is not constant, because it oscillates around its trend (that is, around the potential GDP which can be produced with the existence of the balanced unemployment rate). GDP growth is the goal of every forward and dynamic economy. Its trends are analysed in longer intervals.

Three methods of GDP calculation are known: (1) the sum of final sales in a certain time period, (2) the sum of added values, (3) the sum of factorial income from economic activities (Burda \& Wyplosz, 2013; Vinski, 1967). The first definition of GDP, i.e. net final sales (according to which export is a net final sale too), is mainly used because the export of goods or services constitutes national income. GDP calculation is done according to current or permanent prices (nominal and real GDP). As relevant, real GDP is mainly calculated (on the basis of prices from the base year).

The difference between the achieved and potential GDP makes the output "gap". This gap is brought into connection with unemployment rate (the bigger the unemployment rate, the greater the GDP gap).

Unemployment is an expressly negative economic category. It occurs when there are workers willing to work for certain fees but cannot find work. Unemployment is tied to unfavourable economic situations, under-development, crises and shocks (Burda \& Wyplosz, 2013). Unemployment rate is expressed as quotient of the number of unemployed people and the total supply of workforce. It is also connected with the problem of inequality of salary, work productivity and the like. Differences in salaries increase the number of households earning a lot, but also those with lower wages. Just like the output trends, analysis of unemployment is researched together with other indicators, such as inflation, investments and other.

Defining variables and statistical base. Two variables will be used in this paper: GDP growth rate as the dependent variable, and unemployment (as \%) as the independent variable. Statistical base is made of relevant international sources, which can be seen in the following table. 
Table 2. Definitions of variables and statistical sources

\begin{tabular}{clcll}
\hline No & $\begin{array}{c}\text { Name of } \\
\text { indicators }\end{array}$ & $\begin{array}{c}\text { Denotation in } \\
\text { the model }\end{array}$ & Explanation & Source \\
\hline 1 & $\begin{array}{l}\text { GDP } \\
\text { growth, } \\
\text { (annual \%) }\end{array}$ & GDP GROWTH & $\begin{array}{l}\text { Annual percentage growth rate } \\
\text { of GDP at market prices based } \\
\text { on constant local currency. }\end{array}$ & $\begin{array}{l}\text { World Bank national accounts data, } \\
\text { and OECD National Accounts data } \\
\text { files. }\end{array}$ \\
\hline & $\begin{array}{l}\text { Unemploy } \\
\text { ment, total }\end{array}$ & Unemployment & $\begin{array}{l}\text { (\% of total labor force) } \\
\text { (national estimate) }\end{array}$ & $\begin{array}{l}\text { International Labour Organization, } \\
\text { ILOSTAT database. Data retrieved } \\
\text { in June 21, 2020. }\end{array}$ \\
\hline
\end{tabular}

\begin{tabular}{|c|c|c|c|c|}
\hline 3 & GDP & GDP & $\begin{array}{l}\text { GDP at purchaser's prices is the } \\
\text { sum of gross value added by all } \\
\text { resident producers in the } \\
\text { economy plus any product taxes } \\
\text { and minus any subsidies not } \\
\text { included in the value of the } \\
\text { products. It is calculated } \\
\text { without making deductions for } \\
\text { depreciation of fabricated }\end{array}$ & $\begin{array}{l}\text { World Bank national accounts data, } \\
\text { and OECD National Accounts data } \\
\text { files. }\end{array}$ \\
\hline
\end{tabular}

Source: World Bank, WDI, 2020; ILO, 2020.

Regression analysis - methodological approach. The research is based on interdependence between one and the other variable, or many other variables. The dependent variable is the primary one, and its variations can be explained in terms of other independent (regression) variables. The model of stochastic connection between the dependent and independent variables is the regression model. It is expressed as an equation in which the dependent variable $\mathrm{Y}$ is represented as the linear or nonlinear function of independent variables $(\mathrm{x} 1, \mathrm{x} 2, \ldots, \mathrm{xk})$. Stochastic connection $\mathrm{Y}$ and $(\mathrm{x} 1, \mathrm{x} 2, \ldots, \mathrm{xk})$ is characteristic in that every vector of independent variables $(\mathrm{x} 1, \mathrm{x} 2, \ldots ., \mathrm{xk})$ owns a distribution of the values of the dependent variable. By introducing random variable in the model, we have the following:

$$
Y=f\left(\mathrm{x}_{1}, \mathrm{x}_{2}, \ldots, \mathrm{x}_{\mathrm{k}}\right)+\varepsilon
$$

(dependent variable $\mathrm{Y}$ can also be called regressand, endogenous or output variable, whereas the independent variables can be called regressor, exogenous or input variables).

The formula for evaluated function of simple linear regression runs as follows:

$$
\hat{Y} i=b 0+b 1 x i
$$

where: $\hat{Y} i$ - the value of dependent variable (on the best adjusted regression line);

b0 and b1 - unknown regression parameters (which are to be evaluated).

Finally, the simple linear regression model introduces the stochastic character of the linear relation between the dependent $(\mathrm{Y})$ and independent variable $(\mathrm{x})$, so that we have the following:

$$
Y i=\beta 0+\beta 1 \cdot x i+\varepsilon i \quad(i=1, \ldots, n)
$$

where: Yi - i-dependent variable; $x i$ - $\mathrm{i}$-independent variable; $\beta 0, \beta 1$ - regression parameters; $\varepsilon \mathrm{i}-$ stochastic member; $\mathrm{n}$ - the size of the basic set. 


\section{RESEARCH RESULTS}

What follows are the results of the regression analysis, represented in three tables (sections). The first table of the regression model (Model Summary) shows the determination coefficient ( $\mathrm{R}$ Square) 0,204 , which means that $20,4 \%$ GDP variations is determined by unemployment trends. This result is insufficient in the sense of statistical significance and the model quality. However, it is quite logical, as the Gross Domestic Product trends are, in reality, impacted by numerous factors, which have been excluded from the model. In the second section, the results of $\mathrm{F}$ test of regression analysis (variance analysis - ANOVA) show the value of 4,3 and the probability below $5 \%$, which means that the model possesses enough degrees of freedom (df) for mutual variations in the analysed phenomena, and this is statistically acceptable in the sense of significance and for statistical evaluation that has been shown in the third section of the regression model.

Table 3. Model Summary

\begin{tabular}{|c|c|c|c|c|}
\hline Model & $\mathrm{R}$ & R Square & $\begin{array}{l}\text { Adjusted R } \\
\text { Square }\end{array}$ & $\begin{array}{l}\text { Std. Error of the } \\
\text { Estimate }\end{array}$ \\
\hline 1 & $.451^{\mathrm{a}}$ & .204 & .159 & 4.54057 \\
\hline
\end{tabular}

Source: Author's calculations

Table 4. ANOVA ${ }^{\mathrm{a}}$

\begin{tabular}{llrrrrr}
\hline Model & & Sum of Squares & df & Mean Square & F & Sig. \\
\hline 1 & Regression & 94.936 & 1 & 94.936 & 4.605 & $.046^{\mathrm{b}}$ \\
\cline { 2 - 7 } & Residual & 371.102 & 18 & 20.617 & \\
\cline { 2 - 7 } & Total & 466.038 & 19 & & \\
\hline
\end{tabular}

a. Dependent Variable: GDP

b. Predictors: (Constant), Unemployment

Source: Author's calculations

The third section (Coefficients) shows the variable coefficient as regression predictor (Unemployment) and its significance for GDP trends. Unemployment variable negatively and statistically significantly determines GDP trends. Unemployment change by one unit inversely determines the Gross Domestic Product trends by 0,596 units. Hence it can be concluded that $\mathrm{BiH}$ has inversely proportional direction of unemployment and Gross Domestic Product trends for the period 2000-2019.

Table 5. Coefficientsa

\begin{tabular}{|c|c|c|c|c|c|c|}
\hline \multirow{2}{*}{\multicolumn{2}{|c|}{ Model }} & \multicolumn{2}{|c|}{ Unstandardized Coefficients } & \multirow{2}{*}{$\begin{array}{c}\text { Standardized } \\
\text { Coefficients }\end{array}$} & \multirow[b]{2}{*}{$\mathrm{t}$} & \multirow[b]{2}{*}{ Sig. } \\
\hline & & B & Std. Error & & & \\
\hline \multirow[t]{2}{*}{1} & (Constant) & 30.420 & 7.381 & & 4.121 & .001 \\
\hline & Unemployment & -.596 & .278 & -.451 & -2.146 & .046 \\
\hline
\end{tabular}

Source: Author's calculations

a. Dependent Variable: GDP

Source: Author's calculations

Reasons for weaker intensity of negative correlation between the observed variables can be found in unfavourable structure of the economy of Bosnia and Herzegovina. For, mostly goods with lower value added are being produced, so that GDP growth tempo faster than $0,6 \%$ (Okun finds that one percent reduction of unemployment ensures GDP growth of 2-2,5\%) cannot be attained. 


\section{DISCUSSION AND CONCLUSION}

Theproblems of economicgrowth represent fundamental issuesin economicscience, and newanswers are continuously being sought. One of the classic economic hypotheses pertains to determining the existence of interdependence between GDP or its growth rates and unemployment. In contrast to Phillips regularity, which implies a choice between two markedly negative macroeconomic phenomena, Okun's regularity considers the relations between one positive phenomenon (GDP growth) and one negative phenomenon (unemployment). Therefore, the research shows the relation between GDP (GDP growth rates) as a macroeconomic aggregate and unemployment rate as a macroeconomic indicator. It is known that GDP growth has the greatest impact on economic welfare, whereas unemployment erodes the social foundation of the community; in particular, if there is a pronounced difference between the achieved and potential GDP, which is called "output gap" in literature.

In the context of this research, the economy of Bosnia and Herzegovina in the period 2000-2019 has been included, as well as determination of the relation between GDP and unemployment rate trends. According to numerous researches, it has been established that this relation has been based on the coefficient 2,5 or even 2. That is, unemployment growth impacts the decrease in GDP by $2-2,5 \%$ (previous researches had shown somewhat bigger values).

Okun's regularity for Bosnian and Herzegovinian economy for the period 2000-2019 shows results similar to the researches so far. Truth be, the results of linear regression analysis show that there is complete coincidence between the variables GDP (output) and unemployment, in the direction of the phenomena, as the correlation is negative $(\mathrm{R}=0,451)$. Further, determination coefficient is $\mathrm{R} 2=0,204$ and shows that $20,4 \%$ GDP variations is determined by changes in unemployment. The intensity of connection is somewhat weaker, which is shown by the coefficient $\beta$ in the equation of the linear regression, amounting to $-0,596$. Hence, change in unemployment by 1 percentile point impacts on (causes) inverse change in GDP by approximately 0,6 units.

The starting hypothesis has been proven, because the direction of variables points to the existence of Okun's regularity, but the intensity of connection (effect) between the variables is somewhat weaker. These results prove that there exists negative functional relation between the output market and labour market in Bosnia and Herzegovina, which is the basis of Okun's regularity. Also, unfavourable economic structure is the main reason of somewhat weaker connection between the observed variables (0,6 instead of 2,0). Economic policy creators are advised to speed up measures on employment growth, but also to implement structural changes faster, as in this way they will bring about an increase in GDP growth rate, which in turn will lead to the growth of economic and social welfare. In principle, measures are recommended vis-a-vis increasing investments (local and foreign ones), improvement of business environment, structural reforms, growth of export and the like. All of these stated activities require that the processes of European integrations be sped up. 


\section{REFERENCES}

Baily, M., \& Friedman, P. (1991). Macroeconomics, financial markets, and the international sector, Richard D. Irwin. Inc., Boston, MA.

Burda, M., Wyplosz, Ch. (2013). Macroeconomics: European Text. 6th Edition. Oxford University Press.

Cahill, M. B. (2006). Estimating key macroeconomic relationships at the undergraduate level: Taylor rule and Okun's Law examples. In Meeting of the Allied Social Science Associations Boston, MA. Retrieved from: https://www.holycross.edu/sites/default/files/files/economics/faculty/ cahill/cahillmilesaea2006paper.pdf

Dajcman, S. (2018). A Regional Panel Approach to testing the Validity of Okun's Law: the Case of Slovenia. Economic Computation \& Economic Cybernetics Studies \& Research, 52(3). https://doi.org/10.24818/18423264/52.3.18.03

Dixon,R., Lim, G.C., \& van Ours, J.C. (2017) Revisiting the Okun relationship, Applied Economics, 49(28), 2749-2765, DOI: 10.1080/00036846.2016.1245846

Moazzami, B., \& Dadgostar, B. (2009). Okuns Law Revisited: Evidence From OECD Countries. International Business \& Economics Research Journal (IBER), 8(8). Retrieved: https://core. ac.uk/reader/268106610

Okun, A. M. (1962). Potential GNP, its measurement and significance. Cowles Foundation, Yale University. Retrieved from: https://milescorak.files.wordpress.com/2016/01/okunpotential-gnp-its-measurement-and-significance-p0190.pdf

Pizzo, A. (2020). Literature review of empirical studies on Okun's law in Latin America and the Caribbean. International Labour Organization. (No. 995063292502676). Retrieved from: https://www.ilo.org/wcmsp5/groups/public/---ed_emp/---ifp_skills/documents/ publication/wcms_734508.pdf

Popović, G. (2010) Inflation and unemployment: Phillips regularity in the EU, Conference Procceeding, Sarajevo Busines and Economics Review, 30.

Samuelson, P. A., \& Nordhaus, W. D. (2007). Ekonomija, 18. izdanje. McGraw-Hill/MATE doo Zagreb.

Vinski, I. (1967) Uvod u analizu nacionalnog dohotka i bogatstva, Zagreb: Naprijed.

World Bank (2020a). Retreived from: https://data.worldbank.org/indicator/SL.UEM.TOTL. NE.ZS?locations $=B A$

World Bank (2020b). Retreived from: https://data.worldbank.org/indicator/NY.GDP.MKTP. KD.ZG?locations $=B A$ 